\title{
Evaluation of Structural Implication of Incorporating Base Isolator as Earthquake Protection Device
}

\author{
Md.Arman Chowdhury ${ }^{1}$, Rajib Kumar Biswas ${ }^{2,}$ Md.Nazmul Haq ${ }^{3}$ \\ Syeed Md. Iskander ${ }^{4}$ \\ ${ }^{1}$ (Graduate student, Department of Civil Engineering, Ahsanullah University of Science and Technology) \\ ${ }^{2}$ (Undergraduate student, Department of Civil Engineering, Ahsanullah University of Science and Technology) \\ ${ }^{3}$ (Graduate student, Department of Civil Engineering, Bangladesh University of Engineering and Technology) \\ ${ }^{4}$ (Lecturer, Department of Civil Engineering, Ahsanullah University of Science and Technology)
}

\begin{abstract}
Introduction of the flexible element at the base of a structure and at the same time ensuring damping is probably the best option for the seismic isolation technique. The device that meets such criteria is known as isolator. In this study incorporation of such base isolator in buildings has been investigated. A study was done considering different building with different plan to justify the applicability of base isolation. The characteristics and performance effect of a building with and without base isolator system were compared. Study shows the applicability of base isolator to the range up to buildings of $30 \mathrm{~m}-40 \mathrm{~m}$ height. The installation of isolator in building considerably increases the time period of building, which means it reduces the possibility of resonance of the structure. Provision of isolator in building often increases the total cost, but reinforcement requirement and construction material cost is reduced due to isolator. So, isolator may be incorporated at the bottom of the building to exploit economic and structurally safe alternative.
\end{abstract}

Keywords: Equivalent Static Analysis, Time history method, Base Isolation, Reinforce concrete building.

\section{Introduction}

Historical seismic catalogues reveal that Bangladesh has been affected by earthquake since ancient times. Earthquakes occurred in 1664, 1828, 1852 and 1885 are shown to have Dhaka as epicentral area.

Similarly cities like Rangpur, Sylhet, Mymensing, Chittagong, Saidpur, Sirajgong, Pabna etc. have been shown to be the epicentral area of some of the major earthquakes in the past. Although the ancient record do not specify the earthquake epicenter by giving coordinates in terms of latitude and longitude. It is difficult to figure out whether these cities were directly hit by earthquakes. However occurrence of earthquakes both inside and outside of the country and around major cities indicates that earthquake hazard exists for the country in general and the cities in particular. Consideration of earthquake forces in structural design, city planning and infrastructure development is therefore a prerequisite for future disaster mitigation.

Several earthquake of large magnitude (Richter magnitude 7.0 or higher) with epicenters within Bangladesh and India close to Indo-Bangladesh have occurred (AM and Chowdhury, 1994). Table 1 and Table 2 provide lists of the major earthquakes that have affected Bangladesh and its surroundings. Furthermore the country is divided into three zones determined from the earthquake magnitude for various return periods and the acceleration attenuation relationship (Ali and Chowdhury, 1994) namely zones 1,2,3 being most to least severe gradually (BNBC, 1993).

Table 1. Lists of Major Earthquakes Affecting Bangladesh

\begin{tabular}{|c|c|c|c|}
\hline Date of occurrence & Name (Place) & Magnitude & $\begin{array}{c}\text { Epicenter distance } \\
\text { from Dhaka(Km) }\end{array}$ \\
\hline 10 Jan 1869 & Cachar Earthquake & 7.5 & 250 \\
\hline 14 Jul 1885 & Bengal earthquake(Bogra) & 7.0 & 170 \\
\hline 12 Jun 1897 & Great Indian Earthquake & 8.7 & 230 \\
\hline 08 Jul 1918 & $\begin{array}{c}\text { Srimangal Earthquake } \\
\text { (Srimangal) }\end{array}$ & 7.6 & 150 \\
\hline 02 Jul 1930 & Dhubri Earthquake & 7.1 & 250 \\
\hline 15 Jan 1934 & Bihar-Nepal Earthquake(Bihar) & 8.3 & 510 \\
\hline 15 Aug 1950 & Asam Earthquake (Aasm) & 8.5 & 780 \\
\hline
\end{tabular}


Table 2. Recent Major earthquakes in Bangladesh (Ansary, 2005)

\begin{tabular}{|c|c|c|c|}
\hline Date of Occurrence & Name( Place) & Magnitude & $\begin{array}{c}\text { Epicentral distance } \\
\text { from Dhaka (Km) }\end{array}$ \\
\hline 08 May 1997 & $\begin{array}{c}\text { Sylhet Earthquake } \\
\text { (Sylhet) }\end{array}$ & 6.0 & 210 \\
\hline 21 Nov 1997 & $\begin{array}{c}\text { Chittagong Earthquake } \\
\text { (Chittagong) }\end{array}$ & 5.5 & 264 \\
\hline 22 Jul 1999 & $\begin{array}{c}\text { Moheskhali Earthquake } \\
\text { (Cox's Bazar) }\end{array}$ & 5.2 & 300 \\
\hline 27 Jul 2003 & Chittagong-Rangamati Earthquake & 5.9 & 290 \\
\hline
\end{tabular}

The historical seismicity data of Bangladesh and adjoining areas indicate that Bangladesh is vulnerable to earthquake hazards. As Bangladesh is the world's most densely populated area, any future earthquake shall affect more people per unit area than any other seismically active regions of the world. Both of the above factors call for evaluation of seismic hazard of Bangladesh so that proper hazard mitigation measure may be undertaken before it is too late.

The basic objective of the research is to: 1) Conduct a through literature survey on the base isolation principle and its suitability for use in buildings. 2) Perform non linear dynamic analysis of buildings with isolated bearings and non-isolated one.

The investigation gives emphasis on the feasibility of incorporation of isolators and its structural implication on buildings is limited to the following extents: 1) Only buildings in Dhaka are considered in this work. 2) Two types of isolators namely high damping rubber bearing and lead rubber bearing is considered in this research.

\section{MODAL ANALYSIS}

A base isolated demonstration building has been considered in Dhaka, Bangladesh as part of an ongoing effort to promote the use of base isolation technology for common structures in earthquake-prone developing countries. The superstructure of the demonstration building I a ten-story reinforced concrete frame.

A specially developed isolation system for this project consisted of 25 lead rubber bearings which were connected to all the column and foundation using recessed-type connections at the ground level. Developed sitespecific spectra were used for the design of the isolation system. The building is of 4 spacing @ $7.62 \mathrm{~m} \mathrm{c} / \mathrm{c}$ in both directions. Chosen properties are: $\mathrm{f}^{\prime} \mathrm{c}=28 \mathrm{MPa}, \mathrm{f}_{\mathrm{y}}=414 \mathrm{MPa}$, dead load (excluding self weight) $=4.8 \mathrm{KPa}$, Live load $=2.4 \mathrm{KPa}$, slab thickness $=150 \mathrm{~mm}$, Exterior corner column are all $\mathrm{C1}=750 \times 750 \mathrm{~mm}$, Exterior middle column are all C2 $=950 \times 950 \mathrm{~mm}$, Interior columns are all C3 $=1000 \times 1000 \mathrm{~mm}$, Grade beams are $\mathrm{GB}=300 \times 375 \mathrm{~mm}$, and beam $\mathrm{B} 1=525 \times 825 \mathrm{~mm}$ each, beam $\mathrm{B} 2=600 \times 900 \mathrm{~mm}$ each, beam B3 $=550 \times 900 \mathrm{~mm}$ each. SAP2000 version 15 was used for Analysis and Design.

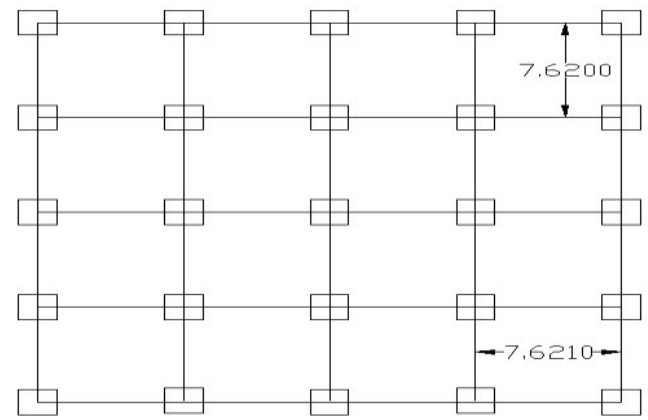

Figure 1: Plan of the Building

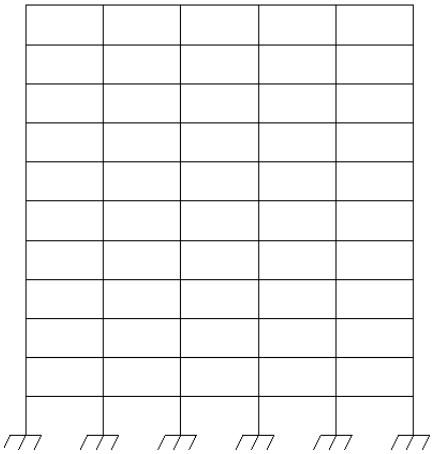

Figure 2: Elevation view of the building 


\section{DESIGN EARTHQUAKE FOR DYNAMIC ANALYSIS}

There is a lack of suitable earthquake result in Bangladesh. In this study an earthquake record obtained at lacc nor-1.th (Figure 3) and lacc nor-2.th (Figure 4) is used for the analysis.

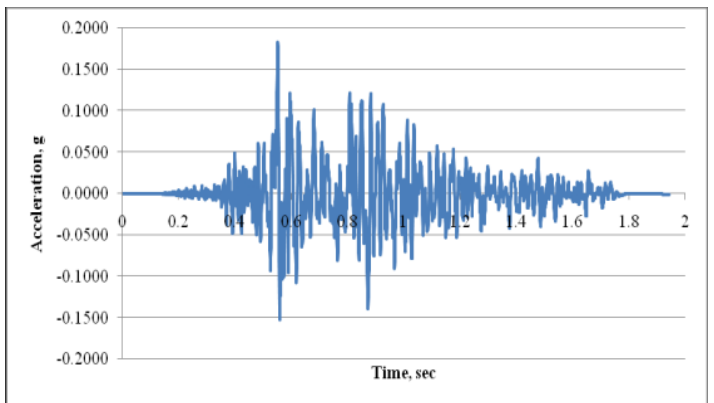

Figure 3: lacc_nor-1.th

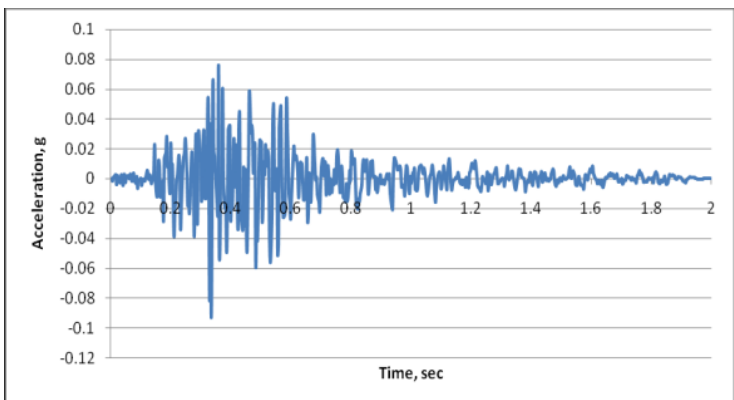

Figure 4: lacc_nor-2.th

\section{Linear static analysis}

\section{RESULT AND DISCUSSIONS}

From Table 3 we can see that design shear for earthquake loading is greater than that for wind loading and the structural time period is in within the reasonable value of $0.1-1.0 \mathrm{sec}$ which is within maximum severity range. (Soleimanloo, 2012) Again here lateral load due to wind is less than $10 \%$ of the weight of the building which is another criteria for using the base isolation concept. So, we can incorporate isolator at the base of the structure to justify more about the feasibility of base isolation.

Table 3: Data obtained after static analysis without isolator

\begin{tabular}{|c|c|}
\hline Structural Time period & 0.913 \\
\hline Design Base Shear (EQ load) & $4785 \mathrm{KN}$ \\
\hline Design Base Shear (Wind Load) & $2789 \mathrm{KN}$ \\
\hline Top story displacement in U1 direction (EQ load) & $13.70 \mathrm{~mm}$ \\
\hline Top story displacement in U2 direction (EQ load) & $11.8 \mathrm{~mm}$ \\
\hline Top story displacement in U1 direction (Wind load) & $7.0 \mathrm{~mm}$ \\
\hline Top story displacement in U2 direction (Wind load) & $6.8 \mathrm{~mm}$ \\
\hline Total weight of the Building & $128040 \mathrm{KN}$ \\
\hline Governing axial load under column C3(Linear analysis) & $7190 \mathrm{KN}$ \\
\hline Governing axial load under column C2(Linear analysis) & $4602 \mathrm{KN}$ \\
\hline Governing axial load under column C1(Linear analysis) & $2575 \mathrm{KN}$ \\
\hline
\end{tabular}

\section{Time History Analysis}

A Non linear time history analysis was performed by choosing appropriate time history i.e. ground motion that resembles the site condition of the structure. We have selected here lacc nor-1.TH in the X direction and lacc nor-2.TH in the Y direction. Here result for dynamic analysis is shown in Table 4.

Table 4: Data obtained after dynamic analysis without using isolator (Time history analysis)

\begin{tabular}{|c|c|}
\hline Design Base Shear in X direction & $19590 \mathrm{KN}$ \\
\hline Design Base Shear in Y direction & $14495 \mathrm{KN}$ \\
\hline Design Base Moment in X direction & $123690 \mathrm{KN}-\mathrm{m}$ \\
\hline Design Base Moment in Y direction & $76770 \mathrm{KN}-\mathrm{m}$ \\
\hline Top story displacement in U1 direction & $33 \mathrm{~mm}$ \\
\hline Top story displacement in U2 direction & $30.8 \mathrm{~mm}$ \\
\hline
\end{tabular}




\section{Result of Analysis using Isolator}

Assigning the value of the stiffness to the isolators and analyzing the structure with isolator by SAP2000 we get the following result (Table 5a and 5b). The seismic performance is evaluated for the maximum seismic events.

Table 5.a: Displacement after dynamic analysis using isolator

\begin{tabular}{|l|c|c|}
\hline & Isolator displacement $(\mathrm{mm})$ & Total structural drift $(\mathrm{mm})$ \\
\hline U1 Direction( static Analysis) & 151.6 & 56.3 \\
\hline U2 Direction (Static Analysis) & 145.8 & 53.1 \\
\hline U1 Direction (Time History Analysis) & 119.1 & 30.1 \\
\hline U2 Direction (Time History Analysis) & 73.8 & 28.6 \\
\hline Structural period for model & \multicolumn{2}{|c|}{$2.85 \mathrm{sec}$} \\
\hline
\end{tabular}

Table 5.b: Base Shear and Base Moment after dynamic analysis using isolator

\begin{tabular}{|l|c|}
\hline & Time history analysis \\
\hline Design Base Shear in X direction & $7803 \mathrm{KN}$ \\
\hline Design Base Shear in Y direction & $4837.3 \mathrm{KN}$ \\
\hline Design Base Moment in X direction & $43932.1 \mathrm{KN}-\mathrm{m}$ \\
\hline Design Base Moment in Y direction & $26930.8 \mathrm{KN}-\mathrm{m}$ \\
\hline
\end{tabular}

All Values of maximum displacements at Table 6 lie below the design displacement $292.61 \mathrm{~mm}$. So, the isolator properties are satisfactory.

Table 6: Comparison of Drift in isolated and non-isolated structure

\begin{tabular}{|l|c|c|c|c|}
\hline \multicolumn{2}{|c|}{} & \multicolumn{1}{c|}{$\begin{array}{c}\text { Base displacement } \\
(\mathrm{mm})\end{array}$} & $\begin{array}{c}\text { Top displacement } \\
(\mathrm{mm})\end{array}$ & $\begin{array}{c}\text { Total structure } \\
\text { drift }(\mathrm{mm})\end{array}$ \\
\hline \multirow{2}{*}{$\begin{array}{l}\text { Isolated } \\
\text { Building }\end{array}$} & $\mathrm{U} 1$ & 119.1 & 149.2 & 30.1 \\
\cline { 2 - 5 } & $\mathrm{U} 2$ & 73.8 & 102.4 & 28.6 \\
\hline $\begin{array}{l}\text { Non Isolated } \\
\text { Building }\end{array}$ & $\mathrm{U} 1$ & 12.59 & 133.35 & 120.76 \\
\cline { 2 - 5 } & $\mathrm{U} 2$ & 3.23 & 37.57 & 40.8 \\
\hline
\end{tabular}

\section{CONCLUSION}

Seismic response and characteristics of an isolated and non-isolated building is studied using the finite element method by SAP 2000. An elaborate investigation of the influence of various parameters involved in isolation is performed. For the detail analysis and design, static analysis along with time history analysis is executed. After an extensive and systemic study, the following conclusions may be drawn:

1) The period for the seismically isolated structures are much greater compared to that of the fixed based structure.

2) There is a fixed based soft storey in the first floor, but the addition of the base isolation system corrects this problem (rigid motion of the whole structure).

3) Design base shear due to the presence of isolator is reduced by about 2.5 to 3 times in Time History Analysis.

4) Design Base Moment is reduced by about 2.8 to 2.85 times in Time History Analysis after using Base Isolator.

5) Top displacement of isolated building decreases by about 2 to 4 times than non-isolated building.

So, installation of isolator provides the greater safety to the building.

\section{REFERENCES}

[1] Ali, M.H and Choudhury, J.R. (1994) "Seismic zoning of Bangladesh" Paper presented at the International Seminar on Recent Developments in " Earthquake Disaster Mitigation", Institute of Engineers, Bangladesh.

[2] Ansary, M.A., Al-Hussaini, T.M., Sharfuddin, M and Chowdhury, J.R. (1999), " Report on Moheskhali Earthquake of July 22 , 1999”, earthquake Engineering series, Research Report No. BUET/CE/EQE-99-01, Department of Civil Engineering, BUET, August, 1999.

[3] Bangladesh National Building Code (BNBC, 1993) Published by Housing and Building Research Institute and Bangladesh Standard and Testing Institute, Bangladesh.

[4] Naeim, F. Kelly,J.(1999) "Design of seismic isolated structure". John Wiley \& Sons,Inc.

[5] Wang, Yen-Po, "Fundamentals of Seismic Base Isolation" International Training Programs for Seismic Design of Building Structures.

[6] H.S.Soleimanloo (2012)" A Survey study on design procedure of seismic base isolation system”JASEM,2012.

[7] SAP2000(2005), A general purpose Linear and Non-Linear analysis program, Computers and Structures. 